\title{
Obesity in China: its characteristics, diagnostic criteria, and implications
}

\author{
Weiping Jia \\ Disease, Shanghai 200233, China \\ (C) Higher Education Press and Springer-Verlag Berlin Heidelberg 2015
}

Department of Endocrinology and Metabolism, Shanghai Jiao Tong University Affiliated Sixth People's Hospital, Shanghai Clinical Center for Diabetes, Shanghai Diabetes Institute, Shanghai Key Laboratory of Diabetes Mellitus, Shanghai Key Clinical Center for Metabolic

\section{Introduction}

The rising prevalence of overweight and obesity in several countries has been described as a global pandemic. Obesity and obesity-related diseases are increasing dramatically and have become a massive burden on world economy and global health. In 2010, overweight and obesity were estimated to cause 3.4 million deaths, with $4 \%$ of years of life lost and $4 \%$ of disability-adjusted life-years worldwide [1]. Abdominal obesity, also known as central obesity, refers to the presence of excess fat in the abdominal area. Epidemiological studies have demonstrated that obesity, especially central obesity, is associated with many metabolic disorders, such as impaired glucose tolerance, hypertension, dyslipidemia, and proinflammatory status. This editorial mainly discusses the prevalence of obesity, associated changes over the past decade, the criteria of central obesity, and its implications on cardiovascular disease (CVD).

\section{The epidemiology of obesity and associated changes over the past decade}

The prevalence of obesity has increased dramatically worldwide over the last decades and has now reached epidemic proportions. Worldwide, the age-standardized prevalence of obesity nearly doubled from $6.4 \%$ in 1980 to $12.0 \%$ in 2008 , and the age-standardized prevalence of overweight increased from $24.6 \%$ to $34.4 \%$ during the same 28 -year period [2]. In some regions, such as Europe, the Eastern Mediterranean, and the Americas, more than $50 \%$ of women are overweight. China and the United States experienced the largest absolute increase in the number of overweight and obese people between 1980 and 2008 [3]. Another recently published paper in the Lancet estimated the global, regional, and national

Correspondence: wpjia@sjtu.edu.cn prevalence of overweight and obesity in children and adults during 1980-2013. The number of overweight $\left(25 \mathrm{~kg} / \mathrm{m}^{2} \leqslant\right.$ body mass index $\left.(\mathrm{BMI})<30 \mathrm{~kg} / \mathrm{m}^{2}\right)$ and obese (BMI $\geqslant 30 \mathrm{~kg} / \mathrm{m}^{2}$ ) individuals increased from 857 million in 1980 to 2.1 billion in 2013. The prevalence of combined overweight and obesity rose by $27.5 \%$ for adults and $47.1 \%$ for children between 1980 and 2013 [4].

Similarly, the prevalence rates of overweight, obesity, and central obesity have also increased greatly over the past decade in China [5]. The analysis from the China National Diabetes and Metabolic Disorders Study [6] showed that $31.4 \%$ and $12.2 \%$ (approximately 299.5 and 116.2 million, respectively) of Chinese adults are overweight and obese in 2012, respectively, according to the Chinese WGOC definition (overweight and obese are defined as BMI between 24 and $28 \mathrm{~kg} / \mathrm{m}^{2}$ and BMI $\geqslant 28 \mathrm{~kg} / \mathrm{m}^{2}$, respectively [7]). On the contrary, the prevalence of overweight and obesity in Chinese adults was $16.4 \%$ and $3.6 \%$ in 1992 [8], and $22.8 \%$ and $7.1 \%$ in 2002, respectively [9]. The Shanghai Diabetes Study [10] conducted in 1998-2001 and in 2007-2008 found that the standardized mean BMI in men increased from $23.5 \mathrm{~kg} / \mathrm{m}^{2}$ in the $1998-2001$ survey to $24.1 \mathrm{~kg} / \mathrm{m}^{2}$ in the $2007-2008$ survey. The standardized mean waist circumference was 77.7 $\mathrm{cm}$ and $79.9 \mathrm{~cm}$ in the 1998-2001 and 2007-2008 survey, respectively. The increases in obesity prevalence in China could be attributed to the environmental changes that promote excessive food intake and discourage physical activity. Conclusively, because of the established health risks and substantial increases in prevalence, obesity has become a major global health challenge. Urgent global action and leadership are needed to address this problem.

\section{Central obesity and cardiovascular disease}

Obesity is strongly associated with metabolic disorders, CVD, and an increased risk of morbidity and mortality [1113]. Each year, 28 million individuals are dying from the 
consequences of overweight or obesity worldwide [14]. The relationship between obesity and the development of CVD is now overwhelmingly clear. Large prospective studies, such as the Framingham Heart Study, the Manitoba Study, and the Harvard School of Public Health Nurses Study, have documented obesity as an independent predictor of CVD [15-17].

The relationship between obesity and CVD depends not only on the amount of total body fat but also on its distribution [18]. Compared with total body fat, visceral fat accumulation is more important for the development of insulin resistance, metabolic syndrome, type 2 diabetes, and CVD $[19,20]$. The famous Framingham Heart Study revealed that the prevalence of hypertension impaired fasting glucose, whereas increased the metabolic syndrome linearly and significantly across increasing visceral adipose tissue volume quartiles among overweight and obese individuals. Compared with subcutaneous abdominal adipose tissue, visceral adipose tissue volume remains more strongly associated with an adverse metabolic risk profile [21]. A Japanese study, the VACATION-J study, found a similar result. The coexistence of visceral fat (visceral adipose tissue volume $\geqslant 100 \mathrm{~cm}^{2}$ ) and risk factor accumulations (i.e., hypertension, glucose intolerance, and/or dyslipidemia) is strongly associated with coronary artery disease in the Japanese population [22]. Moreover, the study in Shanghai by Zhang et al. [23] revealed that the CVD incidence was independently related to increased waist circumference in the middle-aged group and to elevated blood glucose in the elderly group. Our group previously found that after a $10.5 \mathrm{~cm}$ increment of waist circumference, a 1.7-fold or 2.2-fold greater risk of having diabetes or diabetes plus dyslipidemia exists compared with BMI alone [6].

The presence of obesity throughout lifetime is positively related to atherosclerosis development as measured by carotid intimal-medial thickness (C-IMT). The quantitative assessment of C-IMT is accepted as an indicator of preclinical atherosclerosis and may be used as a marker for cardiovascular morbidity and mortality [24,25]. Recently, some studies have discussed obesity, specifically central obesity, and its relation to C-IMT [26]. A study by Wang et al. [27] revealed that visceral fat accumulation, but not BMI, was independently correlated with C-IMT in men free of CVD.

Waist circumference is known to be one of the independent risk factors of C-IMT. Thus, research has been performed to explore the optimal waist circumference cut-off in identifying C-IMT elevation. One study carried out in women [28] found that the C-IMT was significantly higher in those with a waist circumference $\geqslant 85 \mathrm{~cm}$ than in those with a waist circumference $<85 \mathrm{~cm}$. C-IMT significantly increased with increasing waist circumference and reached a platform of about 85 $\mathrm{cm}$. Zhang et al. [29] tracked Chinese male patients with newly diagnosed diabetes after an average of almost two years and concluded that a significant elevation of C-IMT exists in the group of patients with a baseline waist circumference greater than $90 \mathrm{~cm}$. Collectively, a waist circumference greater than $85 \mathrm{~cm}$ in women and $90 \mathrm{~cm}$ in men is associated with preclinical atherosclerosis. These two cut-off values are also the criteria of central obesity in China, as we will discuss in the next section.

\section{Criteria of central obesity}

In 2005, the International Diabetes Federation (IDF) proposed a unified worldwide definition of the metabolic syndrome. In this definition, central obesity was regarded as a prerequisite and incorporated element with different waist circumference cut-offs by gender and ethnicity, in which a waist circumference of $90 \mathrm{~cm}$ and $80 \mathrm{~cm}$ was proposed for Chinese men and women, respectively; however, the IDF left the cut-offs flexible until better data validated these values [30].

An important study led by Bao et al. [31] explored the appropriate cut-offs for the visceral fat area measured by magnetic resonance imaging, which links the risk of metabolic syndrome and the corresponding waist circumference in a Chinese population. The study found that the optimal visceral fat area cut-off in identifying the metabolic syndrome with two or more components was near $80 \mathrm{~cm}^{2}$, and the optimal waist circumference cut-off for visceral obesity is $90 \mathrm{~cm}$ and $85 \mathrm{~cm}$ in men and women, respectively. These results were included in the Chinese Joint Committee for Developing Chinese Guideline [32].

The above cut-off results in the Chinese population are consistent with other studies in Asian populations. Ye et al. [33] carried out a 7.8-year follow-up study in a Shanghai urban area and observed that the appropriate waist circumference cut-offs for central obesity are $88 \mathrm{~cm}$ and $82 \mathrm{~cm}$ for men and women in the Chinese population, respectively. A Korean study has defined $84 \mathrm{~cm}$ as the optimal waist circumference cut-off in women [34]. Kashihara et al. [35] from Japan found that the discriminated values of the visceral fat area were $103.0 \mathrm{~cm}^{2}$ and $69.0 \mathrm{~cm}^{2}$, whereas the waist circumference values corresponding to the visceral fat area were $89.1 \mathrm{~cm}$ and $86.3 \mathrm{~cm}$ for men and women, respectively. Nakamura et al. [36] found that the optimal waist circumference cut-off to detect the clustering cardiovascular risk factors for the metabolic syndrome in Japan was $88 \mathrm{~cm}$ and $82 \mathrm{~cm}$ for men and women, respectively.

\section{Obesity assessment}

The most commonly used anthropometric tool to assess relative weight and classify obesity is the BMI, which is expressed as the ratio of total body weight over height squared $\left(\mathrm{kg} / \mathrm{m}^{2}\right)$. The parameter of BMI is not very discriminant to distinguish lean from fat body mass, particularly among patients with a BMI $\geqslant 30 \mathrm{~kg} / \mathrm{m}^{2}$ [37]. The BMI alone seems to present a U- or a J-shaped association with clinical outcomes and mortality [38]. Such 
an inverse relationship fuels a controversy in the literature, named the "obesity paradox," which associates better survival and fewer CVD events in patients with mildly elevated BMI afflicted with chronic diseases [37,39]. A possible explanation for this paradox could be found in body fat distribution. For instance, markers of absolute and relative accumulation of abdominal fat, such as elevated waist circumference and waist-to-hip ratio (WHR), have been associated with an increased risk of myocardial infarction, heart failure, and total mortality in patients with CVD [40].

Therefore, waist circumference is a widely accepted, simple, and non-invasive method to assess central obesity compared with BMI [41,42]; however, waist circumference cannot distinguish visceral adiposity from subcutaneous adiposity. The standard methods for quantifying visceral fat amount recommended by the IDF are magnetic resonance imaging and computed tomography to measure the visceral fat area as a precise indicator for visceral obesity [30], but the inconvenience and high cost limit its use. In addition to waist circumference, various anthropometric measures of obesity have been observed to be related to cardiovascular and allcause mortality. In a recent study in Europeans [43], BMI, waist circumference, waist-to-height ratio, body shape index, and waist-to-hip-to-height ratio were measured. Over a median follow-up of 7.9 years, the authors found that the BMI had a J-shaped relationship with CVD mortality, whereas anthropometric measures of central obesity had positive linear relationships. Accordingly, a threshold value was detected at $29.29 \mathrm{~kg} / \mathrm{m}^{2}$ and $30.98 \mathrm{~kg} / \mathrm{m}^{2}$ for BMI, and $96.4 \mathrm{~cm}$ and $93.3 \mathrm{~cm}$ for waist circumference with CVD mortality in men and women, respectively; and at $29.88 \mathrm{~kg} / \mathrm{m}^{2}$ and $29.50 \mathrm{~kg} / \mathrm{m}^{2}$ for BMI, and $104.3 \mathrm{~cm}$ and $105.6 \mathrm{~cm}$ for waist circumference in men and women, respectively, with all-cause mortality.

Therefore, BMI, waist circumference, visceral fat area measurement, and other anthropometric measures of obesity are all widely used measurements of obesity; each has its own merits and shortcomings. Researchers can choose among the above measurements according to their study design and practical condition.

\section{Perspectives}

Despite the efforts devoted in recent years, an urgent need for obesity monitoring and control still exists. Currently, we understand that obesity, specifically central obesity, is a very important risk factor for the metabolic syndrome, type 2 diabetes and CVD. As an initial step, we need to emphasize the identification of "at risk" overweight/obese individuals in clinical practice to better assess and manage patients' care and to use our limited health care resources optimally.

Second, simple tools and strategies are required. Perhaps, the time has come to consider a new paradigm in which simple tools are used to redefine higher risk overweight/ obesity (such as waist circumference) and new therapeutic objectives. A new model such as this can be experimentally tested.

Third, ideally, nationally representative surveys in countries should be repeated at regular intervals. In managing overweight/obese children and adult populations, continuing the collection of information regarding body weight and height, at a minimum, to monitor obesity trends over time is required to compare data across different countries. Over the past few decades, the global emergence of overweight and obesity is confounded by the simultaneous aging of the population [44]. A high prevalence of overweight and obesity occurs in elder adults. Thus, population aging may contribute independently to the rising prevalence of overweight and obesity in adults. Population aging may differ by country and over time. Therefore, the age-adjusted prevalence for overweight and obesity is needed to allow the comparisons of prevalence and trends across countries. Increased investment in population obesity monitoring would improve the accuracy of forecasts and evaluations.

Finally, a comprehensive understanding of obesity is important to recognize the common pathophysiology of CVD or diabetes and to motivate people to take appropriate interventions aimed at risk reduction of CVD and diabetes. Governments and health providers should regard this important health risk as a key global health priority in both developing and developed countries because obesity has become a major public health challenge in many middleincome countries.

\section{Compliance with ethics guidelines}

Weiping Jia declares that she has no conflict of interest. This manuscript is an editorial and does not involve a research protocol requiring approval by the relevant institutional review board or ethics committee.

\section{References}

1. Lim SS, Vos T, Flaxman AD, Danaei G, Shibuya K, Adair-Rohani H, Amann M, Anderson HR, Andrews KG, Aryee M, Atkinson C, Bacchus LJ, Bahalim AN, Balakrishnan K, Balmes J, Barker-Collo S, Baxter A, Bell ML, Blore JD, Blyth F, Bonner C, Borges G, Bourne R, Boussinesq M, Brauer M, Brooks P, Bruce NG, Brunekreef B, Bryan-Hancock C, Bucello C, Buchbinder R, Bull F, Burnett RT, Byers TE, Calabria B, Carapetis J, Carnahan E, Chafe Z, Charlson F, Chen H, Chen JS, Cheng AT, Child JC, Cohen A, Colson KE, Cowie BC, Darby S, Darling S, Davis A, Degenhardt L, Dentener F, Des Jarlais DC, Devries K, Dherani M, Ding EL, Dorsey ER, Driscoll T, Edmond K, Ali SE, Engell RE, Erwin PJ, Fahimi S, Falder G, Farzadfar F, Ferrari A, Finucane MM, Flaxman S, Fowkes FG, Freedman G, Freeman MK, Gakidou E, Ghosh S, Giovannucci E, Gmel G, Graham K, Grainger R, Grant B, Gunnell D, Gutierrez HR, Hall W, Hoek HW, Hogan A, Hosgood HD 3rd, Hoy D, Hu H, Hubbell BJ, Hutchings SJ, Ibeanusi SE, Jacklyn GL, Jasrasaria R, Jonas JB, Kan H, Kanis JA, Kassebaum N, Kawakami 
N, Khang YH, Khatibzadeh S, Khoo JP, Kok C, Laden F, Lalloo R, Lan Q, Lathlean T, Leasher JL, Leigh J, Li Y, Lin JK, Lipshultz SE, London S, Lozano R, Lu Y, Mak J, Malekzadeh R, Mallinger L, Marcenes W, March L, Marks R, Martin R, McGale P, McGrath J, Mehta S, Mensah GA, Merriman TR, Micha R, Michaud C, Mishra V, Mohd Hanafiah K, Mokdad AA, Morawska L, Mozaffarian D, Murphy T, Naghavi M, Neal B, Nelson PK, Nolla JM, Norman R, Olives C, Omer SB, Orchard J, Osborne R, Ostro B, Page A, Pandey KD, Parry CD, Passmore E, Patra J, Pearce N, Pelizzari PM, Petzold M, Phillips MR, Pope D, Pope CA 3rd, Powles J, Rao M, Razavi H, Rehfuess EA, Rehm JT, Ritz B, Rivara FP, Roberts T, Robinson C, Rodriguez-Portales JA, Romieu I, Room R, Rosenfeld LC, Roy A, Rushton L, Salomon JA, Sampson U, Sanchez-Riera L, Sanman E, Sapkota A, Seedat S, Shi P, Shield K, Shivakoti R, Singh GM, Sleet DA, Smith E, Smith KR, Stapelberg NJ, Steenland K, Stöckl H, Stovner LJ, Straif K, Straney L, Thurston GD, Tran JH, Van Dingenen R, van Donkelaar A, Veerman JL, Vijayakumar L, Weintraub R, Weissman MM, White RA, Whiteford H, Wiersma ST, Wilkinson JD, Williams HC, Williams W, Wilson N, Woolf AD, Yip P, Zielinski JM, Lopez AD, Murray CJ, Ezzati M, AlMazroa MA, Memish ZA. A comparative risk assessment of burden of disease and injury attributable to 67 risk factors and risk factor clusters in 21 regions, 1990-2010: a systematic analysis for the Global Burden of Disease Study 2010. Lancet 2012; 380(9859): 2224-2260

2. Stevens GA, Singh GM, Lu Y, Danaei G, Lin JK, Finucane MM, Bahalim AN, McIntire RK, Gutierrez HR, Cowan M, Paciorek CJ, Farzadfar F, Riley L, Ezzati M; Global Burden of Metabolic Risk Factors of Chronic Diseases Collaborating Group (Body Mass Index). National, regional, and global trends in adult overweight and obesity prevalences. Popul Health Metr 2012; 10(1): 22

3. Pérez Rodrigo C. Current mapping of obesity. Nutr Hosp 2013; 28 (Suppl 5): 21-31

4. Ng M, Fleming T, Robinson M, Thomson B, Graetz N, Margono C, Mullany EC, Biryukov S, Abbafati C, Abera SF, Abraham JP, AbuRmeileh NM, Achoki T, AlBuhairan FS, Alemu ZA, Alfonso R, Ali MK, Ali R, Guzman NA, Ammar W, Anwari P, Banerjee A, Barquera S, Basu S, Bennett DA, Bhutta Z, Blore J, Cabral N, Nonato IC, Chang JC, Chowdhury R, Courville KJ, Criqui MH, Cundiff DK, Dabhadkar KC, Dandona L, Davis A, Dayama A, Dharmaratne SD, Ding EL, Durrani AM, Esteghamati A, Farzadfar F, Fay DF, Feigin VL, Flaxman A, Forouzanfar MH, Goto A, Green MA, Gupta R, Hafezi-Nejad N, Hankey GJ, Harewood HC, Havmoeller R, Hay S, Hernandez L, Husseini A, Idrisov BT, Ikeda N, Islami F, Jahangir E, Jassal SK, Jee SH, Jeffreys M, Jonas JB, Kabagambe EK, Khalifa SE, Kengne AP, Khader YS, Khang YH, Kim D, Kimokoti RW, Kinge JM, Kokubo Y, Kosen S, Kwan G, Lai T, Leinsalu M, Li Y, Liang X, Liu S, Logroscino G, Lotufo PA, Lu Y, Ma J, Mainoo NK, Mensah GA, Merriman TR, Mokdad AH, Moschandreas J, Naghavi M, Naheed A, Nand D, Narayan KM, Nelson EL, Neuhouser ML, Nisar MI, Ohkubo T, Oti SO, Pedroza A, Prabhakaran D, Roy N, Sampson U, Seo H, Sepanlou SG, Shibuya K, Shiri R, Shiue I, Singh GM, Singh JA, Skirbekk V, Stapelberg NJ, Sturua L, Sykes BL, Tobias M, Tran BX, Trasande L, Toyoshima $\mathrm{H}$, van de Vijver S, Vasankari TJ, Veerman JL, Velasquez-Melendez G, Vlassov VV, Vollset SE, Vos T, Wang C, Wang X, Weiderpass E, Werdecker A, Wright JL, Yang YC, Yatsuya H, Yoon J, Yoon SJ, Zhao Y, Zhou M, Zhu S, Lopez AD, Murray
CJ, Gakidou E. Global, regional, and national prevalence of overweight and obesity in children and adults during 1980-2013: a systematic analysis for the Global Burden of Disease Study 2013. Lancet 2014; 384(9945): 766-781

5. Xi B, Liang Y, He T, Reilly KH, Hu Y, Wang Q, Yan Y, Mi J. Secular trends in the prevalence of general and abdominal obesity among Chinese adults, 1993-2009. Obes Rev 2012; 13(3): 287-296

6. Hou X, Lu J, Weng J, Ji L, Shan Z, Liu J, Tian H, Ji Q, Zhu D, Ge J, Lin L, Chen L, Guo X, Zhao Z, Li Q, Zhou Z, Shan G, Yang Z, Yang W, Jia W; China National Diabetes and Metabolic Disorders Study Group. Impact of waist circumference and body mass index on risk of cardiometabolic disorder and cardiovascular disease in Chinese adults: a national diabetes and metabolic disorders survey. PLoS ONE 2013; 8(3): e57319

7. Zhou BF; Cooperative Meta-Analysis Group of the Working Group on Obesity in China. Predictive values of body mass index and waist circumference for risk factors of certain related diseases in Chinese adults - study on optimal cut-off points of body mass index and waist circumference in Chinese adults. Biomed Environ Sci 2002; 15(1): 83-96

8. Ge K. The Dietary and Nutritional Status of the Chinese Population: 1992 National Nutrition Survey, vol. 1. Beijing: People's Medical Publishing House, 1996 (in Chinese)

9. Wang LD. 2002 Nutrition and Health Survey of Chinese Residents. Beijing: People's Medical Publishing House, 2005: 50-51 (in Chinese)

10. Hou X, Liu Y, Lu H, Ma X, Hu C, Bao Y, Jia W. Ten-year changes in the prevalence of overweight, obesity and central obesity among the Chinese adults in urban Shanghai, 1998-2007 - comparison of two cross-sectional surveys. BMC Public Health 2013; 13(1): 1064

11. Eckel RH, Krauss RM. American Heart Association call to action: obesity as a major risk factor for coronary heart disease. Circulation 1998; 97(21): 2099-2100

12. Poirier P, Eckel RH. Obesity and cardiovascular disease. Curr Atheroscler Rep 2002; 4(6): 448-453

13. Eckel RH, Barouch WW, Ershow AG. Report of the National Heart, Lung, and Blood Institute-National Institute of Diabetes and Digestive and Kidney Diseases Working Group on the pathophysiology of obesity-associated cardiovascular disease. Circulation 2002; 105(24): 2923-2928

14. Bastien M, Poirier P, Lemieux I, Després JP. Overview of epidemiology and contribution of obesity to cardiovascular disease. Prog Cardiovasc Dis 2014; 56(4): 369-381

15. Rabkin SW, Mathewson FA, Hsu PH. Relation of body weight to development of ischemic heart disease in a cohort of young North American men after a 26 year observation period: the Manitoba Study. Am J Cardiol 1977; 39(3): 452-458

16. Hubert HB, Feinleib M, McNamara PM, Castelli WP. Obesity as an independent risk factor for cardiovascular disease: a 26-year followup of participants in the Framingham Heart Study. Circulation 1983; 67(5): 968-977

17. Wilson PW, D'Agostino RB, Sullivan L, Parise H, Kannel WB. Overweight and obesity as determinants of cardiovascular risk: the Framingham experience. Arch Intern Med 2002; 162(16): 18671872

18. Harman-Boehm I, Blüher M, Redel H, Sion-Vardy N, Ovadia S, Avinoach E, Shai I, Klöting N, Stumvoll M, Bashan N, Rudich A. Macrophage infiltration into omental versus subcutaneous fat across 
different populations: effect of regional adiposity and the comorbidities of obesity. J Clin Endocrinol Metab 2007; 92(6): 2240-2247

19. [No authors listed]. Executive summary of the clinical guidelines on the identification, evaluation, and treatment of overweight and obesity in adults. Arch Intern Med 1998; 158(17): 1855-1867

20. Poirier $P$, Lemieux I, Mauriège $P$, Dewailly E, Blanchet $C$, Bergeron J, Després JP. Impact of waist circumference on the relationship between blood pressure and insulin: the Quebec Health Survey. Hypertension 2005; 45(3): 363-367

21. Fox CS, Massaro JM, Hoffmann U, Pou KM, Maurovich-Horvat P, Liu CY, Vasan RS, Murabito JM, Meigs JB, Cupples LA, D'Agostino RB Sr, O'Donnell CJ. Abdominal visceral and subcutaneous adipose tissue compartments: association with metabolic risk factors in the Framingham Heart Study. Circulation 2007; 116(1): 39-48

22. Hiuge-Shimizu A, Kishida K, Funahashi T, Okutsu M, Kametani R, Kobayashi H, Nozaki Y, Nomura A, Yokoi H, Yoshizumi T, Ohira T, Nakamura T, Matsuzawa Y, Sumitsuji S, Shimomura I. Coexistence of visceral fat and multiple risk factor accumulations is strongly associated with coronary artery disease in Japanese (the VACATION-J study). J Atheroscler Thromb 2012; 19(7): 657663

23. Zhang ML, Hou XH, Zhu YX, Lu JX, Peng LP, Gu HL, Jia WP. Metabolic disorders increase the risk to incident cardiovascular disease in middle-aged and elderly Chinese. Biomed Environ Sci 2012; 25(1): 38-45

24. Grobbee DE, Bots ML. Carotid artery intima-media thickness as an indicator of generalized atherosclerosis. J Intern Med 1994; 236(5): 567-573

25. Lorenz MW, Markus HS, Bots ML, Rosvall M, Sitzer M. Prediction of clinical cardiovascular events with carotid intima-media thickness: a systematic review and meta-analysis. Circulation 2007; 115 (4): 459-467

26. Agarwal S, Jacobs DR Jr, Vaidya D, Sibley CT, Jorgensen NW, Rotter J, Chen YD, Liu Y, Andrews JS, Kritchevsky S, Goodpaster B, Kanaya A, Newman AB, Simonsick EM, Herrington DM. Metabolic syndrome derived from principal component analysis and incident cardiovascular events: The Multi Ethnic Study of Atherosclerosis (MESA) and Health, Aging, and Body Composition (Health ABC). Cardiol Res Pract 2012; 2012: 919425

27. Wang Y, Ma X, Zhou M, Zong W, Zhang L, Hao Y, Zhu J, Xiao Y, Li D, Bao Y, Jia W. Contribution of visceral fat accumulation to carotid intima-media thickness in a Chinese population. Int J Obes 2012; 36(9): 1203-1208

28. Shen Y, Zhang L, Zong WH, Wang Z, Zhang Y, Yang MJ, Ma XJ, Zhu JA, Bao YQ, Jia WP. Correlation between waist circumference and carotid intima-media thickness in women from Shanghai, China. Biomed Environ Sci 2013; 26(7): 531-538

29. Zhang L, Shen Y, Zhou J, Pan JM, Yu HY, Chen HB, Li Q, Li M, Bao YQ, Jia WP. Relationship between waist circumference and elevation of carotid intima-media thickness in newly-diagnosed diabetic patients. Biomed Environ Sci 2014; 27(5): 335-342

30. Alberti KG, Zimmet P, Shaw J. Metabolic syndrome - a new worldwide definition. A Consensus Statement from the International Diabetes Federation. Diabet Med 2006; 23(5): 469-480

31. Bao Y, Lu J, Wang C, Yang M, Li H, Zhang X, Zhu J, Lu H, Jia W, Xiang K. Optimal waist circumference cutoffs for abdominal obesity in Chinese. Atherosclerosis 2008; 201(2): 378-384
32. Joint Committee for Developing Chinese guidelines on Prevention and Treatment of Dyslipidemia in Adults. Chinese guidelines on prevention and treatment of dyslipidemia in adults. Chin J Cardiol (Zhonghua Xin Xue Guan Bing Za Zhi) 2007; 35(5): 390-419 (in Chinese)

33. Ye Y, Bao Y, Hou X, Pan X, Wu H, Li H, Wang C, Tang J, Lu H, Xiang K, Jia W. Identification of waist circumference cutoffs for abdominal obesity in the Chinese population: a 7.8-year follow-up study in the Shanghai urban area. Int J Obes 2009; 33(9): 10581062

34. Han JH, Park HS, Kim SM, Lee SY, Kim DJ, Choi WH. Visceral adipose tissue as a predictor for metabolic risk factors in the Korean population. Diabet Med 2008; 25(1): 106-110

35. Kashihara H, Lee JS, Kawakubo K, Tamura M, Akabayashi A. Criteria of waist circumference according to computed tomographymeasured visceral fat area and the clustering of cardiovascular risk factors. Circ J 2009; 73(10): 1881-1886

36. Nakamura K, Nanri H, Hara M, Higaki Y, Imaizumi T, Taguchi N, Sakamoto T, Horita M, Shinchi K, Tanaka K. Optimal cutoff values of waist circumference and the discriminatory performance of other anthropometric indices to detect the clustering of cardiovascular risk factors for metabolic syndrome in Japanese men and women. Environ Health Prev Med 2011; 16(1): 52-60

37. Romero-Corral A, Montori VM, Somers VK, Korinek J, Thomas RJ, Allison TG, Mookadam F, Lopez-Jimenez F. Association of bodyweight with total mortality and with cardiovascular events in coronary artery disease: a systematic review of cohort studies. Lancet 2006; 368(9536): 666-678

38. Calle EE, Thun MJ, Petrelli JM, Rodriguez C, Heath CW Jr. Bodymass index and mortality in a prospective cohort of U.S. adults. N Engl J Med 1999; 341(15): 1097-1105

39. Romero-Corral A, Somers VK, Sierra-Johnson J, Jensen MD, Thomas RJ, Squires RW, Allison TG, Korinek J, Lopez-Jimenez F. Diagnostic performance of body mass index to detect obesity in patients with coronary artery disease. Eur Heart J 2007; 28(17): 2087-2093

40. Dagenais GR, Yi Q, Mann JF, Bosch J, Pogue J, Yusuf S. Prognostic impact of body weight and abdominal obesity in women and men with cardiovascular disease. Am Heart J 2005; 149(1): 54-60

41. Jia WP, Lu JX, Xiang KS, Bao YQ, Lu HJ, Chen L. Prediction of abdominal visceral obesity from body mass index, waist circumference and waist-hip ratio in Chinese adults: receiver operating characteristic curves analysis. Biomed Environ Sci 2003; 16(3): 206-211

42. Brook RD, Bard RL, Rubenfire M, Ridker PM, Rajagopalan S. Usefulness of visceral obesity (waist/hip ratio) in predicting vascular endothelial function in healthy overweight adults. Am J Cardiol 2001; 88(11): 1264-1269

43. Song X, Jousilahti P, Stehouwer CD, Soderberg S, Onat A, Laatikainen T, Yudkin JS, Dankner R, Morris R, Tuomilehto J, Qiao Q; the DECODE Study Group. Cardiovascular and all-cause mortality in relation to various anthropometric measures of obesity in Europeans. Nutr Metab Cardiovasc Dis 2014 Sep 20. pii: S0939-4753(14)00290-7. [Epub ahead of print] doi: 10.1016/j. numecd.2014.09.004

44. Doak CM, Wijnhoven TM, Schokker DF, Visscher TL, Seidell JC. Age standardization in mapping adult overweight and obesity trends in the WHO European Region. Obes Rev 2012; 13(2): 174-191 